\begin{tabular}{|l|c|c|c|c|c|} 
J. Tek. Ling & Vol.11 & No.3 & Hal. 373 - 380 & Jakarta, September 2010 & ISSN 1441-318X \\
\hline
\end{tabular}

\title{
PEMANFAATAN LIMBAH BUAH PISANG DAN AIR KELAPA SEBAGAI BAHAN MEDIA KULTUR JARINGAN ANGGREK BULAN (Phalaenopsis amabilis) TIPE 229
}

\author{
Ira Djajanegara \\ Pusat Teknologi Bioindustri \\ Badan Pengkajian dan Penerapan Teknologi
}

\begin{abstract}
Coconut water and rotten banana fruits are commonly found in traditional markets as organic wastes. One way to overcome the problems caused by these organic wastes is to convert these unuseful matter into an important and economically useful matter by using them as components of tissue culture media. One important commodity that is usually propagated by tissue culture is Phalaenopsis orchid type 229 (Phalaenopsis amabilis). Therefore, it would be more benefit to substitute the expensive chemicals with organic wastes such as coconut water and banana puree.

In this experiment, addition of coconut water and banana pure to the minimum media containing commercial fertilizer red Polyhyponex, sucrose and commercial agar did not show any inhibition of Phalaenopsis orchid plantlet growth. This probably caused by sufficient macro and micro nutrients provided by those organic matter and Polyhyponex fertilizer. Moreover, addition of $100 \mathrm{~mL} / \mathrm{L}$ of coconut water and $100 \mathrm{mg} / \mathrm{L}$ banana puree gave the optimum leaf and adventitious shoot formation. On the other hand, addition of $150 \mathrm{~mL} / \mathrm{L}$ coconut water gave the optimum height and root formation. In this case, growing Phalaenopsis orchid plantlet should be done in 2 subculture period. The first subculture is to obtain maximum amount of leaf and shhot formation while the second subculture is to obtain optimum height and root formation.
\end{abstract}

Key words : Waste, coconut water, banana puree, tissue culture, Phalaenopsis orchi

\section{PENDAHULUAN}

Sebagian besar produk pertanian merupakan bahan pangan yang tidak dapat disimpan dalam jangka waktu lama. Buah pisang (Musa parasidica) terutama jenis pisang ambon adalah salah satu contohnya. Buah pisang ambon akan bertahan selama 3 hari dan sesudahnya akan membusuk dengan cepat sehingga tidak dapat dijual dan menjadi limbah di pasar. Demikian juga dengan air kelapa (Cocos nucifera) yang banyak terbuang setiap harinya. Walaupun banyak industri yang memanfaatkan limbah air kelapa sebagai bahan bakunya, jumlah air kelapa yang terbuang sebagai limbah per harinya tetap lebih besar dan menjadi masalah bagi kebersihan pasar tradisional. Salah satu upaya memanfaatkan limbahlimbah tersebut menjadi bahan yang lebih berguna adalah dengan memakai bahanbahan tersebut sebagai media kultur jaringan tanaman anggrek terutama anggrek bulan (Phalaeopnosis amabilis) (Gambar.1). Jenis anggrek ini sangat disukai karena lama mekar bunga Phalaenopsis dapat berlangsung beberapa bulan, sehingga bunga Phalaenopsis sangat tahan lama ${ }^{1)}$ 
Keberhasilan penggunaan metode kultur jaringan sangat tergantung pada jenis media. Media kultur tidak hanya mengandung unsur hara makro dan mikro, tetapi juga karbohidrat sebagai sumber karbon atau bahan organik lainnya. Penambahan bubur pisang, bubur kentang, dan zat nabati lainnya yang memiliki kandungan karbohidrat tinggi dapat meningkatkan pertumbuhan dan diferensiasi sel pada tanaman tertentu.

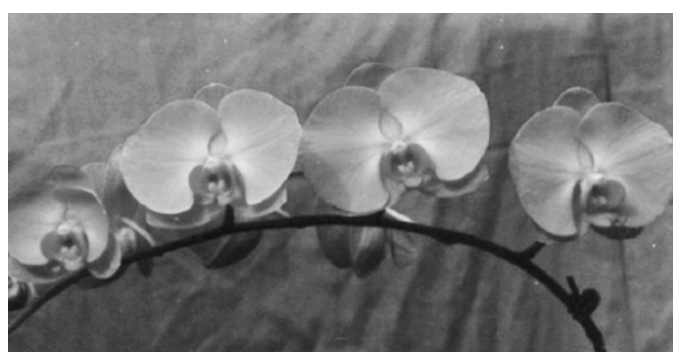

Gambar 1. Bunga anggrek bulan Phalaenopsis amabilis tipe 229

Menurut Gunawan'2), beberapa jenis anggrek membutuhkan vitamin dan hormon untuk memacu pertumbuhan dan perkembangannya. Komposisi unsur-unsur hara, vitamin dan hormon yang terdapat dalam media dasar Vacin and Went yang digunakan dalam perbanyakan anggrek belum cukup untuk memacu pertumbuhan anggrek secara optimal. Menurut Pramesyanti ${ }^{3)}$, secara alami vitamin dan hormon yang diperlukan untuk pertumbuhan anggrek dapat diperoleh dari bahan yang mengandung bahan organik, seperti ekstrak buah-buahan (tomat, pisang ambon, alpukat), dan ekstrak kecambah tanaman (kecambah jagung). Bubur pisang merupakan tambahan zat organik yang umum pada media anggrek untuk memperkaya nutrisi. Penambahan bahan organik kompleks, air kelapa, pisang, pepton, tripton, dan kasein hidrolisat, dalam media kultur dapat meningkatkan pertumbuhan plantlet anggrek. Bahanbahan alami atau zat nabati pada umumnya perupakan sumber gula, vitamin, zat pengatur tumbuh, dan asam amino ${ }^{4,5}$. Salah satu kandungan vitamin yang dimiliki oleh tomat dan pisang adalah tiamin. Vitamin penting yang terkandung pada bahan organik kompleks dan merupakan vitamin yang penting dalam kultur jaringan adalah thiamin 6). Secara umum kandungan yang terdapat dalam 1 buah pisang matang, yaitu protein 1,2 gram, lemak 0,2 gram, karbohidrat 25,3 $\mathrm{mg}$, serat 0,7 gram, kalsium $8 \mathrm{mg}$, fosfor 28 $\mathrm{mg}$, dan besi $0,5 \mathrm{mg}$, zat yang berupa fosfor tersebut baik bagi pertumbuhan tanaman anggrek ${ }^{3}$. Konsentrasi bubur pisang yang biasa digunakan dalam untuk kegiatan kultur jaringan berkisar antara 150-200 g// ${ }^{6}$.

Menurut Widiastoety \& Syafril ${ }^{7)}$, pemberian air kelapa $150 \mathrm{ml} / \mathrm{l}$ ditambah sukrosa $20 \mathrm{~g} / \mathrm{l}$ dalam media kultur memberikan hasil yang baik terhadap protocorm like bodies (plbs) anggrek dendrobium. Pemberian air kelapa $150 \mathrm{ml} / \mathrm{l}$ tanpa pemberian sukrosa memberikan hasil yang baik terhadap pertumbuhan anggrek vanda $^{8}$. Pemberian air kelapa pada tingkat ketuaan sedang dan muda dapat mendorong pertumbuhan vegetatif plantlet. Penggunaan jenis kelapa genjah hijau dan genjah kuning mempunyai pengaruh yang tidak berbeda dalam merangsang pertumbuhan plantlet 9). Wetter dan Constabel ${ }^{10)}$ menyatakan bahwa selain asam amino air kelapa juga mengandung asam organik, asam nukleotida, purin, gula, gula alkohol, vitamin (thiamin, asam ascorbat, dll), zat pengatur tumbuh dan mineral. Sukrosa merupakan kandungan gula tertinggi yang terdapat dalam air kelapa. Menurut Prihatin ${ }^{11)}$, kandungan sukrosa dalam air kelapa yang ditambahkan dalam media sudah cukup bagi sumber energi bagi pertumbuhan dan perkembangan jaringan yang dikulturkan. Sandra ${ }^{12)}$ menuliskan bahwa air kelapa biasanya ditambahkan ke dalam media dengan konsentrasi 2 sampai $15 \%$ (v/v). Sedangkan Sriyanti dan Wijayani ${ }^{13)}$ menyatakan bahwa konsentrasi air kelapa yang ditambahkan berkisar antara 100 sampai $200 \mathrm{ml} / \mathrm{l}$.

Mengacu pada pemikiran tersebut di atas, maka dalam penelitian ini digunakan air kelapa dan bubur berbagai jenis pisang 
dalam kondisi matang sebagai bahan organik tambahan. Jenis pisang yang dipakai dalam penelitian ini antara lain pisang ambon, pisang mas, pisang raja dan pisang kepok (Gambar. 1). Selain hormon dan vitamin, unsur-unsur dan senyawa-senyawa yang terkandung dalam air kelapa dan bubur pisang diperkirakan dapat meningkatkan pertumbuhan anggrek bulan.

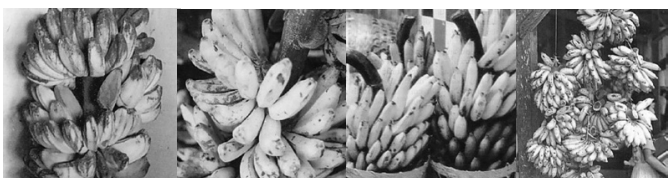

Gambar1: Pisang mas, pisang raja bulu, pisang kepok dan pisang ambonSumber:http:/ featikabsinjai.blogspot. com/2008/06/pisang-kepokkuning.html

Penelitian ini bertujuan mendapatkan bahan organik tambahan yang berasal dari buah pisang matang dan air kelapa yang memiliki pengaruh baik pada pertumbuhan plantlet anggrek bulan (Phalaenopsis amabilis). Diharapkan penambahan bubur pisang dan air kelapa dalam media dapat digunakan sebagai pengganti vitamin dan hormon pertumbuhan yang mahal harganya. Hipotesis yang diajukan dalam penelitian ini adalah dengan penambahan bahan organik bubur pisang dan air kelapa dapat mempercepat pertumbuhan plantlet anggrek bulan.

\section{METODOLOGI}

Penelitian dilakukan di laboratorium tanaman hias Balai Benih Induk Pasar Minggu Jakrta Selatan. Penelitian dilakukan pada bulan Januari sampai dengan Mei 2009. Bahan tanaman yang digunakan adalah plantlet batang dari anggrek Phalaenopsis amabilis tipe 229 dengan ukuran tinggi 1 sampai $2 \mathrm{~cm}$, jumlah daun dua sampai tiga helai dan tanpa akar. Bahan tanaman ini dalam keadaan steril dan belum pernah disubkultur sebelumnya. Dalam penelitian ini prosentase kontaminasi sebesar $12 \%$ (data tidak ditampilkan) yang merupakan kisaran yang wajar dalam kultur jaringan tanaman anggrek. Mayoritas kontaminan adalah jamur.

Media yang digunakan adalah media alternatif yang mengandung pupuk lengkap Polyhyponex merah $2.5 \mathrm{~g} / \mathrm{l}$, trypton $2 \mathrm{~g} / \mathrm{l}$, gula $20 \mathrm{~g} / \mathrm{l}$, arang aktif $1 \mathrm{~g} / \mathrm{l}$ dan $7 \mathrm{~g} / \mathrm{l}$ agaragar. Sebagai perlakuan adalah bubur pisang (pisang mas, pisang raja, pisang ambon dan pisang kepok) dan air kelapa yang ditambahkan ke dalam media dasar alternatif tadi. Sebanyak $100 \mathrm{~g} / \mathrm{l}$ bubur berbagai jenis pisang ditambahakan ke dalam media. Sedangkan penambahan air kelapa dilakukan pada berbagai macam konsentrasi yaitu 50, 100, 150, 200 dan $250 \mathrm{~g} / \mathrm{l}$. Sumber karbon didapat dari gula sedangkan sumber Nitrogen, Fosfat dan Kalium didapat dari pupuk Polyhyponex merah dan trypton. Sumber unsur mikro, vitamin dan zat pengatur tumbuh diharapkan didapat dari bahan organik kompleks yang ditambahkan yaitu bubur pisang dan air kelapa.

Penelitian Perlakuan ini disusun dalam rancangan acak lengkap dengan 25 perlakuan 24 perlakuan dengan air kelapa dan pisang dan 1 perlakuan tanpa air kelapa dan pisang (sebagai kontrol) dan masing- masing perlakuan tersebut dilakukan pengulangan sebanyak 15 kali. Seperti pada tabel kombinasi sebagai berikut;

Tabel 1.Tabel Kombinasi Konsentrasi Air Kelapa dan Berbagai Jenis Pisang

\begin{tabular}{|l|l|l|l|l|l|}
\hline & $\mathbf{P}_{0}$ & $\mathbf{P}_{1}$ & $\mathbf{P}_{2}$ & $\mathbf{P}_{3}$ & $\mathbf{P}_{4}$ \\
\hline $\mathbf{A}_{0}$ & $\mathrm{~A}_{0} \mathrm{P}_{0}$ & $\mathrm{~A}_{0} \mathrm{P}_{1}$ & $\mathrm{~A}_{0} \mathrm{P}_{2}$ & $\mathrm{~A}_{0} \mathrm{P}_{3}$ & $\mathrm{~A}_{0} \mathrm{P}_{4}$ \\
\hline $\mathbf{A}_{1}$ & $\mathrm{~A}_{1} \mathrm{P}_{0}$ & $\mathrm{~A}_{1} \mathrm{P}_{1}$ & $\mathrm{~A}_{1} \mathrm{P}_{2}$ & $\mathrm{~A}_{1} \mathrm{P}_{3}$ & $\mathrm{~A}_{1} \mathrm{P}_{4}$ \\
\hline $\mathbf{A}_{2}$ & $\mathrm{~A}_{2} \mathrm{P}_{0}$ & $\mathrm{~A}_{2} \mathrm{P}_{1}$ & $\mathrm{~A}_{2} \mathrm{P}_{2}$ & $\mathrm{~A}_{2} \mathrm{P}_{3}$ & $\mathrm{~A}_{2} \mathrm{P}_{4}$ \\
\hline $\mathbf{A}_{3}$ & $\mathrm{~A}_{3} \mathrm{P}_{0}$ & $\mathrm{~A}_{3} \mathrm{P}_{1}$ & $\mathrm{~A}_{3} \mathrm{P}_{2}$ & $\mathrm{~A}_{3} \mathrm{P}_{3}$ & $\mathrm{~A}_{3} \mathrm{P}_{4}$ \\
\hline $\mathbf{A}_{4}$ & $\mathrm{~A}_{4} \mathrm{P}_{0}$ & $\mathrm{~A}_{4} \mathrm{P}_{1}$ & $\mathrm{~A}_{4} \mathrm{P}_{2}$ & $\mathrm{~A}_{4} \mathrm{P}_{3}$ & $\mathrm{~A}_{4} \mathrm{P}_{4}$ \\
\hline
\end{tabular}


Keterangan:

1. $\mathrm{A}_{0} \mathrm{P}_{0}$; Tanpa Air Kelapa dan Tanpa Pisang

2. $\mathrm{A}_{1} \mathrm{P}_{0}$; Air Kelapa $50 \mathrm{ml} / \mathrm{l}$ dan Tanpa Pisang

3. $\mathrm{A}_{2} \mathrm{P}_{0}$ Air Kelapa $100 \mathrm{ml} / \mathrm{l}$ dan Tanpa Pisang

4. $\quad \mathrm{A}_{3} \mathrm{P}_{0}$; Air Kelapa $150 \mathrm{ml} / /$ dan Tanpa Pisang

5. $\mathrm{A}_{4} \mathrm{P}_{0}$; Air Kelapa $200 \mathrm{ml} / \mathrm{l}$ dan Tanpa Pisang

6. $\mathrm{A}_{0} \mathrm{P}_{1}$; Tanpa Air Kelapa + Pisang Raja $100 \mathrm{gr} / \mathrm{l}$

7. $\mathrm{A}_{1} \mathrm{P}_{1}$; Air Kelapa $50 \mathrm{ml} / \mathrm{l}+$ Pisang Raja $100 \mathrm{gr} / \mathrm{l}$

8. $\mathrm{A}_{2} \mathrm{P}_{1}$; Air Kelapa $100 \mathrm{ml} / \mathrm{l}+$ Pisang Raja $100 \mathrm{gr} / \mathrm{l}$

9. $\quad \mathrm{A}_{3} \mathrm{P}_{1}$; Air Kelapa $150 \mathrm{ml} / \mathrm{l}+$ Pisang Raja 100 gr/l

10. $\mathrm{A}_{4} \mathrm{P}_{1}$; Air Kelapa $200 \mathrm{ml} / \mathrm{l}+$ Pisang Raja $100 \mathrm{gr} / \mathrm{l}$

11. $\mathrm{A}_{0} \mathrm{P}_{2}$; Tanpa Air Kelapa + Pisang Ambon $100 \mathrm{gr} / \mathrm{l}$

12. $\mathrm{A}_{1} \mathrm{P}_{2}$; Air Kelapa $50 \mathrm{ml} / \mathrm{l}+$ Pisang Ambon $100 \mathrm{gr} / \mathrm{l}$

13. $\mathrm{A}_{2} \mathrm{P}_{2}$; Air Kelapa $100 \mathrm{ml} / \mathrm{l}+$ Pisang Ambon $100 \mathrm{gr} / \mathrm{l}$

14. $\mathrm{A}_{3} \mathrm{P}_{2}$; Air Kelapa $150 \mathrm{ml} / \mathrm{l}+$ Pisang Ambon $100 \mathrm{gr} / \mathrm{l}$

15. $\mathrm{A}_{4} \mathrm{P}_{2}$; Air Kelapa $200 \mathrm{ml} / \mathrm{l}+$ Pisang Ambon $100 \mathrm{gr} / \mathrm{l}$

16. $\mathrm{A}_{0} \mathrm{P}_{3}$; Tanpa Air Kelapa + Pisang Kepok 100 gr/l

17. $\mathrm{A}_{1} \mathrm{P}_{3}$; Air Kelapa $50 \mathrm{ml} / \mathrm{l}+$ Pisang Kepok 100 gr/l

18. $\mathrm{A}_{2} \mathrm{P}_{3}$; Air Kelapa $100 \mathrm{ml} / \mathrm{l}+$ Pisang Kepok 100 gr/l

19. $\mathrm{A}_{3} \mathrm{P}_{3}$; Air Kelapa $150 \mathrm{ml} / \mathrm{l}+$ Pisang Kepok 100 gr/l

20. $\mathrm{A}_{4} \mathrm{P}_{3}$; Air Kelapa $200 \mathrm{ml} / \mathrm{l}+$ Pisang Kepok 100 gr/l

21. $\mathrm{A}_{0} \mathrm{P}_{4}$; Tanpa Air Kelapa + Pisang Mas $100 \mathrm{gr} / \mathrm{l}$

22. $\mathrm{A}_{1} \mathrm{P}_{4}$; Air Kelapa $50 \mathrm{ml} / \mathrm{l}+$ Pisang Mas $100 \mathrm{gr} / \mathrm{l}$

23. $\mathrm{A}_{2} \mathrm{P}_{4}$; Air Kelapa $100 \mathrm{ml} / \mathrm{l}+$ Pisang Mas $100 \mathrm{gr} / \mathrm{l}$
24. $\mathrm{A}_{3} \mathrm{P}_{4}$; Air Kelapa $150 \mathrm{ml} / \mathrm{l}+$ Pisang Mas $100 \mathrm{gr} / \mathrm{l}$

25. $\mathrm{A}_{4} \mathrm{P}_{4} ;$ Air Kelapa $200 \mathrm{ml} / \mathrm{l}+$ Pisang Mas $100 \mathrm{gr} / \mathrm{l}$

Pembuatan bubur pisang dilakukan sebagai berikut: Kulit bagian luar dari pisang dibuang, kemudian masing-masing diambil daging buahnya dan ditimbang berdasarkan jumlah yang dibutuhkan. Selanjutnya daging buah diblender (dihancurkan sampai halus), setelah itu dimasukkan ke dalam media alternatif sesuai perlakuan. Plantlet ditanam secara aseptik ke dalam botol kultur. Setiap botol terdiri atas 1 plantlet. Botol kultur diletakkan di dalam ruang kultur yang diberi cahaya lampu TL 40 watt selama delapan jam per hari dengan suhu ruangan berkisar pada $25-27^{\circ} \mathrm{C}$. Pengambilan data dilakukan terhadap plantlet anggrek bulan pada 16 minggu (empat bulan) setelah penanaman. Beberapa parameter yang digunakan untuk mengukur pertumbuhan plantlet, yaitu :

a. Tinggi plantlet, diukur mulai dari pangkal batang sampai ujung daun yang terpanjang.

b. Jumlah daun, dihitung semua daun pada setiap plantlet.

c. Jumlah akar, dihitung semua akar pada setiap plantlet.

d. Jumlah tunas, dihitung jumlah tunas yang terbentuk dari eksplan yang ditanam

\section{HASIL DAN PEMBAHASAN}

Pemberian bubur pisang dan air kelapa memberikan pengaruh pada plantlet anggrek bulan (Phalaenopsis amabilis) tipe 229 (Tabel 2) selama masa 4 bulan di kondisi kultur jaringan. Dari Tabel 2 dibawah ini terlihat bahwa pemberian bubur pisang ambon sebanyak $100 \mathrm{~g} / \mathrm{l}$ dan air kelapa sebanyak $100 \mathrm{~g} / \mathrm{l}$ memberikan pengaruh yang nyata terhadap pembentukan tunas dan jumlah daun. Sedangkan pemberian air kelapa sebanyak $150 \mathrm{~g} / \mathrm{l}$ memacu pertumbuhan batang plantlet sehingga 
dicapai tinggi maksimum serta memacu pembentukan akar sehingga dicapai jumlah akar maksimum.

Pada penelitian ini dipakai media alternatif yang lebih sederhana daripada media Vaccin \& Went yang biasa dipakai pada tanaman anggrek. Pada penelitian ini sumber karbon didapat dari sukrosa, sumber makro nutrien yaitu Nitrogen, Phosphor dan Kalium serta mikro nutrien al $\mathrm{Ca}, \mathrm{Mg}, \mathrm{Fe}$ dll diharapkan dapat dipenuhi dari pupuk Hyponex. Media dasar alternatif ini lebih murah dibandingkan media standar Vaccin \& Went. Adapun sumber vitamin, asam amino dan bahan organik lainnya diharapkan dapat terpenuhi dari air kelapa dan bubur pisang. Secara umum, tidak terlihat pertumbuhan yang terhambat atau kematian dengan pemakaian media alternatif ini. Hal ini menunjukkan bahwa penghematan biaya bahan kimia dalam pembuatan media dapat dilakukan tanpa mengganggu pertumbuhan tanamannya.

Tabel 2. Pengaruh kombinasi konsentrasi air kelapa dan berbagai jenis pisang pada pertumbuhan plantlet Phalaenopsis amabilis

\begin{tabular}{|l|c|c|c|c|}
\hline $\begin{array}{c}\text { Perlakuan } \\
\text { pada media } \\
\text { alternatif }\end{array}$ & $\begin{array}{c}\text { Jumlah } \\
\text { tunas } \\
\text { yang } \\
\text { ter- } \\
\text { bentuk } \\
\text { (\%) }\end{array}$ & $\begin{array}{c}\text { Tinggi } \\
\text { plantlet } \\
\text { (cm) rata- } \\
\text { rata }\end{array}$ & $\begin{array}{c}\text { Jmlh } \\
\text { daun } \\
\text { Rata- } \\
\text { rata }\end{array}$ & $\begin{array}{c}\text { Jmlh } \\
\text { akar } \\
\text { rata- } \\
\text { rata }\end{array}$ \\
\hline $\begin{array}{l}\text { A0P0 (Tanpa } \\
\text { Air Kelapa } \\
\text { dan Tanpa } \\
\text { Pisang) }\end{array}$ & 11 abcd & 2,52 abcdefg & $\begin{array}{l}3,23 \\
\text { abcd }\end{array}$ & \\
\hline $\begin{array}{l}\text { A1P0 (Air } \\
\text { Kelapa } 50 \\
\text { ml/l dan } \\
\text { Tanpa } \\
\text { Pisang) }\end{array}$ & 11 abcd & $3,02 \mathrm{jk}$ & $\begin{array}{l}3,42 \\
\text { abcd }\end{array}$ & \\
\hline $\begin{array}{l}\text { A2P0(Air } \\
\text { Kelapa } \\
\text { 100 ml/l } \\
\text { dan Tanpa } \\
\text { Pisang) }\end{array}$ & 12 bcde & & 2,92 hijk & $\begin{array}{l}3,46 \\
\text { bcde }\end{array}$ \\
\hline
\end{tabular}

\begin{tabular}{|c|c|c|c|c|}
\hline $\begin{array}{c}\text { Perlakuan } \\
\text { pada media } \\
\text { alternatif }\end{array}$ & $\begin{array}{c}\text { Jumlah } \\
\text { tunas } \\
\text { yang } \\
\text { ter- } \\
\text { bentuk } \\
(\%)\end{array}$ & \begin{tabular}{|c|} 
Tinggi \\
plantlet \\
(cm) rata- \\
rata
\end{tabular} & $\begin{array}{l}\text { Jmlh } \\
\text { daun } \\
\text { Rata- } \\
\text { rata }\end{array}$ & $\begin{array}{l}\text { Jmlh } \\
\text { akar } \\
\text { rata- } \\
\text { rata }\end{array}$ \\
\hline \begin{tabular}{|l|} 
A3P0(Air \\
Kelapa \\
$150 \mathrm{ml} / \mathrm{l}$ \\
dan Tanpa \\
Pisang) \\
\end{tabular} & $13^{\text {cdef }}$ & $3,10^{k}$ & $\begin{array}{l}3,35 \\
\text { cdef }\end{array}$ & $5,26^{\prime}$ \\
\hline \begin{tabular}{|l|} 
A4P0(Air \\
Kelapa \\
$200 \mathrm{ml} / \mathrm{l}$ \\
dan Tanpa \\
Pisang) \\
\end{tabular} & $11.2^{\text {abcde }}$ & $2,96 \mathrm{ijk}$ & $\begin{array}{l}3,29 \\
\text { abcde }\end{array}$ & $3,8^{\text {hijk }}$ \\
\hline $\begin{array}{l}\text { A0P1(Air } \\
\text { Kelapa } 50 \\
\text { ml/I + tanpa } \\
\text { pisang) }\end{array}$ & $11.4^{\text {abcde }}$ & 2,43 abcde & $\begin{array}{l}3,06 \\
\text { abcde }\end{array}$ & $\begin{array}{l}3,55 \\
\text { fghij }\end{array}$ \\
\hline $\begin{array}{l}\text { A1P1(Air } \\
\text { Kelapa } 50 \\
\text { ml/l + Pisang } \\
\text { Raja } 100 \mathrm{gr} / \text { ) }\end{array}$ & $8.8^{a}$ & 2,53 abcdefg & 3,32 a & $\begin{array}{l}3,53 \\
\text { efghij }\end{array}$ \\
\hline \begin{tabular}{|l|} 
A2P1(Air \\
Kelapa 100 \\
ml/l + Pisang \\
Raja $100 \mathrm{gr} / \mathrm{l})$ \\
\end{tabular} & $11.3^{\text {abcde }}$ & $2,30^{a}$ & $\begin{array}{l}3,20 \\
\text { abcde }\end{array}$ & $\begin{array}{l}3,51 \\
\text { defghi }\end{array}$ \\
\hline \begin{tabular}{|l|} 
A3P1(Air \\
Kelapa 150 \\
ml/l + Pisang \\
Raja 100 \\
gr/l)
\end{tabular} & $10^{a b c}$ & 2,49 abcdef & $\begin{array}{l}3,36 \\
a b c\end{array}$ & $\begin{array}{l}3,42 \\
\text { cdefghi }\end{array}$ \\
\hline \begin{tabular}{|l|} 
A4P1(Air \\
Kelapa 200 \\
ml/l + Pisang \\
Raja 100 \\
gr/l) \\
\end{tabular} & $10^{a b c}$ & 2,84 ghijk & $\begin{array}{l}3,41 \\
\text { abcde }\end{array}$ & $\begin{array}{l}3,36 \\
\text { cdefgh }\end{array}$ \\
\hline \begin{tabular}{|l} 
A0P2(Tanpa \\
Air Kelapa \\
+ Pisang \\
Ambon 100 \\
gr/l) \\
\end{tabular} & $13^{\text {cdef }}$ & $2,31 \mathrm{abc}$ & $\begin{array}{l}3,25 \\
\text { cdef }\end{array}$ & $\begin{array}{l}3,29 \\
\text { bcdefgh }\end{array}$ \\
\hline \begin{tabular}{|l|} 
A1P2(Air \\
Kelapa 50 \\
$\mathrm{ml} / \mathrm{l}+$ Pisang \\
Ambon 100 \\
$\mathrm{gr} / \mathrm{l})$
\end{tabular} & $11^{\mathrm{abcd}}$ & 2,55 abcdefg & $\begin{array}{l}3,47 \\
\text { abcd }\end{array}$ & $\begin{array}{l}3,25 \\
\text { bcdefg }\end{array}$ \\
\hline \begin{tabular}{|l|} 
A2P2(Air \\
Kelapa 100 \\
ml/l + Pisang \\
Ambon 100 \\
$\mathrm{gr} / \mathrm{l})$ \\
\end{tabular} & $20^{f}$ & 2,55 abcdefg & $3,77^{f}$ & $\begin{array}{l}3,24 \\
\text { bcdefg }\end{array}$ \\
\hline
\end{tabular}




\begin{tabular}{|c|c|c|c|c|}
\hline $\begin{array}{c}\text { Perlakuan } \\
\text { pada media } \\
\text { alternatif }\end{array}$ & $\begin{array}{c}\text { Jumlah } \\
\text { tunas } \\
\text { yang } \\
\text { ter- } \\
\text { bentuk } \\
(\%)\end{array}$ & $\begin{array}{c}\text { Tinggi } \\
\text { plantlet } \\
(\mathrm{cm}) \\
\text { rata- } \\
\text { rata }\end{array}$ & $\begin{array}{l}\text { Jmlh } \\
\text { daun } \\
\text { Rata- } \\
\text { rata }\end{array}$ & $\begin{array}{l}\text { Jmlh } \\
\text { akar } \\
\text { rata- } \\
\text { rata }\end{array}$ \\
\hline $\begin{array}{l}\text { A3P2(Air } \\
\text { Kelapa } 150 \\
\mathrm{ml} / \mathrm{l}+\text { Pisang } \\
\text { Ambon } 100 \mathrm{gr} / \mathrm{l})\end{array}$ & $11.5^{\text {abcde }}$ & $\begin{array}{l}2,72 \\
\text { efghij }\end{array}$ & $\begin{array}{l}3,31 \\
\text { abcde }\end{array}$ & $\begin{array}{l}3,17 \\
\text { bcdefg }\end{array}$ \\
\hline $\begin{array}{l}\text { A4P2(Air } \\
\text { Kelapa } 200 \\
\mathrm{ml} / \mathrm{l}+\text { Pisang } \\
\text { Ambon } 100 \mathrm{gr} / \mathrm{l})\end{array}$ & $11.2^{\text {abcde }}$ & $\begin{array}{l}2,51 \\
\text { abcdefg }\end{array}$ & $\begin{array}{l}3,30 \\
\text { abcde }\end{array}$ & $\begin{array}{l}3,17 \\
\text { abcdefg }\end{array}$ \\
\hline $\begin{array}{l}\text { A0P3(Tanpa } \\
\text { Air Kelapa + } \\
\text { Pisang kepok } \\
100 \mathrm{gr} / \mathrm{l})\end{array}$ & $9^{a}$ & $\begin{array}{l}2,37 \\
\text { abcd }\end{array}$ & $\begin{array}{l}3,05 \\
a\end{array}$ & $\begin{array}{l}3,05 \\
\text { abcdefg }\end{array}$ \\
\hline $\begin{array}{l}\text { A1P3(Air Kelapa } \\
50 \text { ml/l + Pisang } \\
\text { Kepok } 100 \mathrm{gr} / \mathrm{l})\end{array}$ & $11.3^{\text {abcde }}$ & $\begin{array}{l}2,58 \\
\text { abcdefgh }\end{array}$ & $\begin{array}{l}3,37 \\
\text { abcde }\end{array}$ & $\begin{array}{l}3 \\
\text { abcdefg }\end{array}$ \\
\hline $\begin{array}{l}\text { A3P3(Air } \\
\text { Kelapa } 100 \mathrm{ml} / \mathrm{l} \\
+ \text { Pisang Kepok } \\
100 \mathrm{gr} / \mathrm{l})\end{array}$ & $11^{a b c d}$ & $\begin{array}{l}2,44 \\
\text { abcde }\end{array}$ & $\begin{array}{l}3,26 \\
\text { abcd }\end{array}$ & $\begin{array}{l}2,96 \\
\text { abcdef }\end{array}$ \\
\hline $\begin{array}{l}\text { A3P3(Air Kelapa } \\
150 \mathrm{ml} / \mathrm{l}+\text { Pisang } \\
\text { Kepok } 100 \mathrm{gr} / \mathrm{l})\end{array}$ & $10^{a b c}$ & $\begin{array}{l}2,65 \\
\text { bcdefghi }\end{array}$ & $\begin{array}{l}3,15 \\
\mathrm{abc}\end{array}$ & $\begin{array}{l}2,87 \\
\text { abcde }\end{array}$ \\
\hline $\begin{array}{l}\text { A4P3(Air } \\
\text { Kelapa } 200 \mathrm{ml} / \mathrm{l} \\
+ \text { Pisang Kepok } \\
100 \mathrm{gr} / \mathrm{l})\end{array}$ & $11^{a b c d}$ & $2,35 a b c$ & $\begin{array}{l}3,25 \\
\text { abcd }\end{array}$ & $\begin{array}{l}2,8 \\
\text { abcd }\end{array}$ \\
\hline $\begin{array}{l}\text { A0P4(Tanpa Air } \\
\text { Kelapa + Pisang } \\
\text { Mas } 100 \mathrm{gr} / \mathrm{l})\end{array}$ & $9.5^{\mathrm{ab}}$ & $\begin{array}{l}2,71 \\
\text { defghij }\end{array}$ & $\begin{array}{l}3,10 \\
\mathrm{ab}\end{array}$ & $\begin{array}{l}2,77 \\
\text { abcd }\end{array}$ \\
\hline $\begin{array}{l}\text { A1P4(Air } \\
\text { Kelapa } 50 \mathrm{ml} / \mathrm{l}+ \\
\text { Pisang Mas } 100 \\
\mathrm{gr} / \mathrm{l})\end{array}$ & $18.6^{\text {def }}$ & $\begin{array}{l}2,79 \\
\text { fghijk }\end{array}$ & $\begin{array}{l}3,54 \\
\text { def }\end{array}$ & $\begin{array}{l}2,76 \\
\text { abcd }\end{array}$ \\
\hline $\begin{array}{l}\text { A2P4(Air Kelapa } \\
100 \mathrm{ml} / \mathrm{l}+\text { Pisang } \\
\text { Mas } 100 \mathrm{gr} / \mathrm{l})\end{array}$ & 19 ef & $\begin{array}{l}2,68 \\
\text { cdefghij }\end{array}$ & $\begin{array}{l}3,60 \\
\text { ef }\end{array}$ & $2,7 \mathrm{abc}$ \\
\hline $\begin{array}{l}\text { A3P4 (Air } \\
\text { Kelapa } 150 \mathrm{ml} / \mathrm{l} \\
+ \text { Pisang Mas } \\
100 \mathrm{gr} / \mathrm{l})\end{array}$ & 18.2 def & 2,85 ghijk & $\begin{array}{l}3,55 \\
\text { def }\end{array}$ & $\begin{array}{l}2,56 \\
\text { ab }\end{array}$ \\
\hline $\begin{array}{l}\text { A4P4(Air } \\
\text { Kelapa } 200 \mathrm{ml} / \mathrm{l} \\
+ \text { Pisang Mas } \\
100 \mathrm{gr} / \mathrm{l})\end{array}$ & 19 ef & $\begin{array}{l}2,72 \\
\text { efghij }\end{array}$ & $\begin{array}{l}3,58 \\
\text { ef }\end{array}$ & $2,34^{a}$ \\
\hline
\end{tabular}

Keterangan: Huruf yang sama pada kolom yang sama menunjukkan bahwa nilai tidak berbeda nyata menurut uji Duncan taraf $5 \%$
Berdasarkan data pada Tabel 2 terlihat bahwa penambahan bubur pisang ambon sebanyak $100 \mathrm{~g} / \mathrm{l}$ dan air kelapa sebanyak $100 \mathrm{ml} / \mathrm{l}$ memberikan pengaruh yang nyata terhadap pembentukan tunas dan jumlah daun. Hal ini dapat terjadi karena terkecukupinya komponen-komponen yang diperlukan untuk pembentukan tunas dan daun. Pertumbuhan dan perbanyakan daun dan tunas didukung oleh tercukupinya energi $^{14)}$ dalam hal ini adalah gula dalam bentuk sukrosa yang ditambahkan ke media dan gula yang terdapat pada bubur pisang dan air kelapa. Karbohidrat, dalam hal ini glukosa, merupakan kunci utama dalam proses metabolisme tanaman ${ }^{15)}$. Metabolisme adalah reaksi kimia yang memungkinkan adanya kehidupan. Reaksi metabolisme dalam tanaman menghasilkan ribuan senyawa untuk membentuk organ seperti daun, batang dan akar, dan struktur lain yang terdapat pada tanaman ${ }^{14)}$. Menurut Pramesyanti ${ }^{3)}$ pisang ambon mengandung kadar gula paling banyak diantara jenis pisang-pisang lainnya sedangkan menurut Rotinsulu et. al. ${ }^{16)}$, air kelapa mengandung gula dalam bentuk sukrosa, glukosa, fruktosa dan manitol.

Hal lain yang dapat menjelaskan tercapainya kondisi optimum untuk terbentuknya tunas dan daun pada penambahan bubur pisang ambon sebanyak $100 \mathrm{~g} / \mathrm{l}$ dan air kelapa sebanyak $100 \mathrm{ml} / \mathrm{l}$ adalah tersedianya unsur N, K, Mg dan Fe yang terdapat dalam bubur pisang dan air kelapa yang digunakan. Unsur N, K dan Fe berfungsi dalam metabolisme untuk menghasilkan ATP. Unsur Mg sangat diperlukan untuk proses fotosintesis, karena Mg merupakan komponen molekul klorofil dan Fe dibutuhkan untuk pembentukkan klorofil, walaupun $\mathrm{Fe}$ bukan bagian dari molekul klorofil. Unsur Fe juga berperan dalam transfer elektron ${ }^{14)}$, hal ini mungkin juga menyebabkan jumlah daun mencapai optimal.

Menurut literatur, konsentrasi air kelapa yang biasa dipakai adalah $150 \mathrm{ml} / \mathrm{L}$ tanpa penambahan sukrosa ${ }^{8)}$ sedangkan bubur 
pisang biasa diberikan berkisar antara 150$200 \mathrm{~g} / \mathrm{l}^{6}$. Hasil yang didapat pada penelitian ini sedikit berbeda yaitu air kelapa sebanyak $100 \mathrm{ml} / \mathrm{L}$ dan bubur pisang jenis ambon sebanyak $100 \mathrm{mg} / \mathrm{L}$ yang memberikan pertumbuhan tunas dan daun optimum. Hal ini kemungkinan disebabkan telah adanya penambahan sukrosa ke dalam media dan tingginya kandungan gula pada pisang ambon dibanding jenis pisang lain sehingga sedikit konsentrasi air kelapa dan bubur pisang telah memberikan efek maksimum.

Tabel 2 menunjukkan pemberian air kelapa sebanyak $150 \mathrm{ml} / \mathrm{L}$ tanpa bubur pisang memberikan tinggi tanaman dan jumlah akar yang optimum. Air kelapa mengandung thiamin dan hormon pertumbuhan auksin yang dikenal mimicu pembentukan akar ${ }^{10}$ ). Fungsi tiamin adalah untuk mempercepat pembelahan sel pada meristem $a k a r^{8)}$. Diduga thiamin yang terkandung dalam air kelapa merupakan salah satu faktor penyebab penambahan panjang akar plantlet anggrek bulan (Phalaenopsis amabilis) tipe 229 pada penelitian ini.

Penambahan bubur pisang terutama pada konsentrasi tinggi menyebabkan terhambatnya pertumbuhan akar dan tinggi tanaman kemungkinan karena media yang terlalu padat mengakibatkan pori-pori media kecil dan aerasi (pertukaran udara) tidak baik. Hal ini menyebabkan pertumbuhan akar tanaman terhambat sehingga penyerapan unsur-unsur hara dari media oleh akar menjadi tidak maksimal dan berakibat terhambatnya pertumbuhan tanaman. Pertumbuhan akar yang terhambat terlihat dari bentuk akar yang kecil dan pendek. Pertumbuhan tanaman sangat tergantung dari pertumbuhan dan penyebaran akar. Pertumbuhan akar yang baik hanya terjadijika kondisi media tumbuhnya dapat mendukung keperluan akar. Sesuai dengan pendapat Prihatin ${ }^{11)}$ yang menyatakan bahwa akar dapat tumbuh secara normal jika sebagian besar pori media lebih besar daripada diameter akar atau kekuatan tumbuh akar lebih besar dari pada kekuatan media. Pada media yang aerasinya baik, akar tanaman akan berkembang dengan baik, sedangkan pada keadaan kurang menguntungkan sistem perakaran tidak berkembang dengan cepat dan akar menjadi pendek dan sedikit bercabang-cabang.

Lebih lanjut lagi, bubur pisang terutama yang hampir busuk kemungkinan menghasilkan hormon ethylene yang menghambat penambahan tinggi batang. Ehylene banyak dihasilkan pada buah-buahan yang mengalami proses klimakterik dimana salah satu contohnya adalah buah pisang ${ }^{9}$.

Secara keseluruhan penelitian ini membuktikan bahwa media alternatif dengan menggunakan pupuk komersial hyponex yang murah pada konsentrasi pengenceran yang rendah ditambah llimbah air kelapa dan buah pisang mampu mengurangi ongkos pembelian bahan kimia tanpa mengganggu pertumbuhan tanaman anggrek bulan. Kombinasi air kelapa dan bubur pisang ambon sebanyak $100 \mathrm{ml} / \mathrm{L}$ dan $100 \mathrm{mg} / \mathrm{L}$ memberikan efek maksimum pada pembentukan tunas dan daun. Sedangkan pemberian air kelapa sebanyak $150 \mathrm{ml} / \mathrm{L}$ memberikan jumlah akar dan tinggi maksimum. Dalam hal ini, untuk mendapatkan pertumbuhan plantlet yang optimum maka dilakukan perbanyakan tunas pada media dengan air kelapa dan bubur pisang ambon kemudian disubkultur ke media yang mengandung air kelapa saja untuk mendapatkan tinggi maksimum dan pengakaran yang kuat.

\section{KESIMPULAN DAN SARAN}

1. Pemberian limbah air kelapa dan buah pisang ambon memberikan efek positif pada pertumbuhan plantlet anggrek bulan (Phalaenopsis amabilis) tipe 229

2. Pembentukan tunas dan daun maksimum dicapai dengan pemberian air kelapa $100 \mathrm{ml} / \mathrm{L}$ dan bubur pisang ambon $100 \mathrm{mg} / \mathrm{L}$ sedangkan pembentukan akar dan pertambahan tinggi dicapai dengan pemberian air kelapa sebanyak $150 \mathrm{ml} / \mathrm{L}$ 


\section{DAFTAR PUSTAKA}

1. Anonim. 2003. Data ekspor impor tanaman hias anggrek tahun 2000 2001. Biro Pusat Statistik. Jakarta

2. Gunawan, L. W. 1990. Budidaya Anggrek. Penebar Swadaya. Jakarta.

3. Pramesyanti, A. 1999. Pengaruh bubur buah beberapa kutivar pisang terhadap pertumbuhan vegetatif plantlet Dendrobium Kamiya's PridexDendrobium Rulita Beauty pada media Vacin dan Went (1949) modifikasi. Skripsi FMIPA Jurusan Biologi UI, Depok.

4. Ernst, R., J. Arditti and P. L. Healey. 1971. Carbohydrate physiology of orchid seedling.

II.Hydrolysis and effects of oligosaccharides. Am. J. Bot. 58:827-835.

5. Fonnesbech, M. 1972. Organic nutrients in the media for propagation of Cymbidium in vitro.Physiol. Plant. 27:360-364.

6. Muawanah. 2005. Penggunaan Pupuk Hyponex, Ekstrak Tomat, dan Ekstrak Pisang dalam Perbanyakan dan Perbesaran Plantlet Anggrek Dendrobium (Dendrobium canayo) Secara In Vitro. Skripsi FP Jurusan Budidaya Pertanian IPB, Bogor.

7. Widiastoety, D.dan Syafril. 1993. Pengaruh air kelapa terhadap pertumbuhan plbs anggrek dalam medium padat. Bull. Penel. Tan. Hias. 1(1):7-12

8. Widiastoety, D.dan A. Santi. 1994. Pengaruh air kelapa terhadap pertumbuhan protocorm like bodies (plbs) dari anggrek vanda dalam medium cair. J. Hort. 4(2):71-73
9. Rotinsulu, Prihandarini dan Sudiarso. 1998. Pemanfaatan Air Kelapa dalam Berbagai Tingkat Kematangan Pada Media Kultur Jaringan Pisang Barangan (Musa paradisiaca sapientum L.). Laporan Hasil Penelitian. Fakultas Pertanian, Universitas Sam Ratulangi. Manado.

10. Wetter, L. R. dan L, Constabel. 1991. Metode Kultur Jaringan Tanaman. Diterjemahkan oleh Mathilda B Widianto. Penerbit ITB. Bandung.

11. Prihatin, A. I. 1999. Pengaruh Konsentrasi IAA (Indol Asam Asetat) dan Air KelapaTerhadap Pertumbuhan Plantlet Anggrek Dendrobium Jakarta Molek Secara In Vitro. Skripsi. Fakultas Pertanian, Universitas Mercu Buana. Jakarta

12. Sandra, E. 2003. Kultur Jaringan Anggrek Skala Rumah Tangga. Agromedia Pustaka. Jakarta

13. Sriyanti, D. H. dan A, Wijayani. 1994. Teknik Kultur Jaringan "Pengenalan dan Petunjuk Perbanyakan Tanaman Secara Vegetatif Modern". Kanisius. Yogyakarta.

14. Sriyanti, D. H. 2000. PembibitanAnggrek dalam Botol. Kanisius. Yogyakarta.

15 Salisbury, F. B. dan W. R, Cleon. 1995. Fisiologi Tumbuhan Jilid 2. Diterjemahkan oleh Diah R Lukman dan Sumaryono.

Penerbit ITB. Bandung.

16. Widiastoety, D., S. Kusumo, dan Syafni. 1997. Pengaruh tingkat ketuaan air kelapa dan jenis Kelapa terhadap pertumbuhan plantlet anggrek dendrobium. J. Hort.7(3):768-772. 